\title{
Facing COVID-19 through Emergency Online Education Anchored in Khan's Framework: Case of Philippine Teachers in Xi'an, China
}

\author{
Karen Joy Brillo Talidong ${ }^{1}$ (D), Cathy Mae Dabi Toquero ${ }^{2^{*}}$ (1)
}

${ }^{1}$ School of Education, Shaanxi Normal University, Xi'an, CHINA

${ }^{2}$ College of Education, Mindanao State University, General Santos City, PHILIPPINES

*Corresponding Author: cathymaetoquero@gmail.com

Citation: Talidong, K. J. B., \& Toquero, C. M. D. (2021). Facing COVID-19 through Emergency Online Education Anchored in Khan's Framework: Case of Philippine Teachers in Xi'an, China. European Journal of Interactive Multimedia and Education, 2(1), e02104. https://doi.org/10.30935/ejimed/9683

\begin{abstract}
COVID-19 affected not only the lifestyle and socioeconomic conditions of the people worldwide but also the governing affairs of the process of education. To limit the transmission of COVID-19 in the educational sector, teachers worldwide immediately diverted from face-to-face education to a virtual-based education. This abrupt paradigm shift in education posits a challenge to the teachers who are accustomed to the conventional settings as they embark to emergency online teaching classes. Although distance education is a normalcy in many of the institutions globally, it is still new to the context of the Philippine teachers. In this account, an empirical study on the experiences of the Philippine teachers in Xi'an, China was explored to examine the benefits, challenges, and process in the implementation of emergency online education. Results revealed that emergency online teaching fosters benefits to the teachers and learners during this emergency situation. However, the teachers experience challenges dealing with technical issues, lack of instructional design, and other factors which disrupt emergency online education. This article offers positive and negative standpoints of the application of emergency online teaching to address the unprecedented educational issues brought by the pandemic.
\end{abstract}

Keywords: COVID-19, emergency remote teaching, emergency online education, distance education, online teaching, teachers

Received: 31 Aug. $2020 \bullet$ Accepted: 22 Nov. 2020

\section{INTRODUCTION}

COVID-19 was detected in December 2019 which later developed into a pandemic as it made an extensive change (Gondauri, Mikautadze, \& Batiashvili, 2020) that affected not only Wuhan, China but all other countries around the globe. COVID-19 brought a plight into the sphere causing for health emergencies, socio-econmic recession, and academic disentanglement along the progression of the virus transmission. As a result, worldwide community quarantine and school closures ensued to cease the spread of the virus. UNESCO (2020) reported 1, 576, 021, 818 learners out of $91.3 \%$ of total enrolled learners in 188 countries (Toquero, 2020a) have been affected in the virus outbreak as of April 06, 2020.

In China, the continuity of schooling amid the crisis is one of the most important determinants for crafting policies for the education sector. The Chinese government promotes uninterrupted teaching and learning process amid the spread of COVID-19 (Bao, 2020) through the use of virtual-based education. Consequently, teachers are advised to work at home and teach students through emergency online classes to prevent the spread of the virus. This emergency instruction is the only way possible for the education sector to prevent the spread of the virus as there are findings that report asymptomatic cases in some people that can contribute to the virus transmission (Abdulamir \& Hafidh, 2020).

Moreover, most private schools in China were established to teach English language among primary school children (Lin, 2002). In view of this, some private schools that continued to operate were forced to embrace the new ways of delivering education and imparting knowledge to the students. Schools have migrated to virtual education which means that teachers are expected to teach facing the computer or laptop screen instead of having face-to-face classes with their students (Bao, 2020).

Emergency Online Education (EOE) and Emergency Remote Education (ERE) are crisis response terms for online or remote instruction during an emergency. "Following the logic of the exception-that extraordinary times call for extraordinary measuresone common trend in education systems around the world has been to respond to the pandemic with 'emergency eLearning"' (Murphy, 2020, p. 1). As a crisis response strategy, ERE or EOE can address the mounting issues that surround the educational system due to COVID19. ERE/EOE is the application of technology for virtual instruction but making use of temporary access to available and existing instructional support and pedagogy materials. The idea behind ERE or EOE is not to 
recreate a robust planning (Hodges, Moore, Lockee, Trust, \& Bond, 2020) for a virtual-based education but to provide a reliable and practical access to foster education during the time of an emergency or crisis such as the COVID-19 pandemic.

ERE or EOE is a viable solution during a crisis to continue instruction. However, in online learning, "adequate planning and implementation of best practices and innovative strategies is necessary...to successfully introduce and/or expand online education given the challenge" of the pandemic (Palvia, Aeron, Gupta, Mahapatra, Parida, Rosner \& Sindhi, 2018, p. 236). Emergency online education is different from online teaching that requires comprehensive planning since online-based education curriculum can take long months before it can realize student learning (Palvia et al., 2018).

It is important to distinguish EOE from online teaching since wrong assumptions and definitions that what the teachers and institutions are thinking and implementing as online teaching can make distance education more vulnerable to the errors and bad practices due to the crisis (Bozkurt \& Sharma, 2020). This is in contrast to the results of the years that it took for several studies and meta-analysis to prove the effectiveness of online education which can just suddenly vanish due to the misconceptions. Consequently, the appropriate term to use during a crisis is not online teaching, but emergency online/remote teaching- which is practically what a greater majority of the schools worldwide are implementing to deliver virtual education to the students during this COVID-19 pandemic.

Nevertheless, EOE/ERE as a technologically-inclined teaching is still new to numerous teachers since they are used to teaching the traditional way and lack the remote teaching related experiences using technology. As such, they have difficulty in dealing with the new trend in education due to the COVID-19 outbreak (Gewin, 2020). Therefore, the abrupt change in education, specifically in the process of teaching posits a challenge to the teachers as they embark through emergency online/remote teaching. In view of this, teachers are left with no choice but to face their computers or laptop screen and learn the art of emergency remote teaching. Based on this concept, the experiences in emergency online teaching of the Filipino teachers in Xi'an, China were explored in this study. Hence, questions were designed to understand the viewpoints of the Filipino teachers in relation to the benefits, challenges, and process of the implementation of emergency online education.

\section{THEORETICAL FRAMEWORK}

This study was anchored on the octagonal model of Khan (2005) who developed a framework for online learning to guide the institutions that implement educational technology in the teaching and learning process. The model has eight dimensions: pedagogical, institutional, technological, management, interface design, resource support, ethics, and evaluation. For this study, the researchers focused on the pedagogical, institutional, technological, resource support, and management domains. The pedagogical domain establishes the teachers' pedagogical instructions in the emergency remote teaching environment. The insitutional domain also deals with the teachers' support from the administration and students' services. Teachers today face enormous challenges in their transition to emergency online/remote teaching, but emergency online/remote teaching also provides benefits during this emergency and can serve as a viable alternative to give the students with an opportunity to learn despite the crisis (Toquero, 2020b). Moreover, the technological domain in this study dealt with the teachers' challenges and issues that they had met in the integration of the technology. The management describes how the teachers deal with the challenges in the learning environment and the dissemination of information. The resource support explains that the teachers were given online support and necessary materials to foster student learning and make the learning experiences meaningful for them despite the challenging situation due to the crisis. Through the framework, the teachers can create instructional designs (Talidong, 2020) for their transition to emergency e-learning environments. The limitation of the study in relation to the framework - the interface design, ethics, and evaluation were not included as part of the raised questions of the study. Due to the scope and limitations of the aims of the study, these dimensions of the model were excluded from the discussions of the results. The authors (Affouneh, Salha, \& Khlaif, 2020) also asserted that the framework should be used to analyse the emergency online learning experiences based on the context of diverse entities. Hence, this part of the model can also be catered for testing in another study relative to emergency online/remote teaching environments. This framework can serve an approach to design and develop the content (Affouneh, Salha, \& Khlaif, 2020) for emergency online/remote teaching purposes during this time of the pandemic since teachers shifted from the traditional approach to the online learning environments. This e-learning framework is significant to student learning (Talidong, 2020) during this emergency.

\section{METHODOLOGY}

This study applied a qualitative approach through a case study research design to explore the teachers' perceptions on the application of emergency online teaching during the pandemic. It also examines how the teachers experienced the benefits and challenges of implementing the emergency online teaching and how they managed to deal with the challenging circumstances.

\section{Participants and Setting}

Since some of the schools started the emergency online classes amid COVID-19, few Filipino teachers who were employed in different English Training Schools were able to teach the English language among Chinese students. Due to the limited schools which continued to operate, many Filipino teachers went home in the Philippines during winter break. In view of this, only six Filipino teachers from Xian, China were able to participate in this study. They were employed in the online training schools in Xi'an, China.

\section{Instrument and Data Gathering}

A semi-structured questionnaire was created for this study and online data gathering served as a procedure complemented with an online interview. The researchers obtained the consent of the Filipino teachers before the interview process to secure the ethical considerations. Furthermore, these teachers represent the three English Training Schools in Xi'an, China. The duration of collecting the data was from April 20 to April 25, 2020.

\section{Data Analysis}

The responses of the participants in this study was transcribed and before the analysis was done, the transcribed data from the interview 
was returned to the subjects for verification. Moreover, thematic analysis was used to analyze the responses of the Filipino teachers which were then coded into themes and categories. Rich quotes were taken from the transcripts of the teachers' responses to increase trustworthiness of the result and member checks were done along with audit trail of the online interviews. As such, the results of the interview are presented in the next paragraphs.

\section{RESULTS AND DISCUSSION}

Emergency online teaching offered the possibility for obtaining benefits for the Filipino teachers in guiding their Chinese students during virtual instruction. In view of the benefits of emergency online teaching, there were two themes that emerged out of the analysis.

Benefits. The two themes include convenience and collaboration among teachers, students, and parents. Majority of the subjects identified convenience as one of the benefits in emergency online teaching. Teacher 1 considered emergency online teaching as "convenient" considering the "flexible time and location," he also added that emergency online teaching is "easy to administer." This is also supported by Teacher 2 who said "having the perks of managing your own time as you can do the class anywhere/everywhere." Likewise, Teacher 6 gave a clear view of convenience in emergency online teaching as she explained "I believe the benefits of online teaching are working at your own schedule, comfort of working at your own space and not having to deal with the need to travel from home to school every time you have a scheduled class."

Teacher 5: Online teaching is more convenient for both the teacher and the student. Time and location are flexible and it is a lot cheaper than offline classes.

This is exactly why the term Emergency Online Teaching should be used instead of online teaching since teachers' have their beliefs that what they are implementing is online teaching which is a misconception since it is actually EOT. "Looking to move to remote learning to temporarily bridge the gap...desperate educators wanting to immediately convert their courses right in the middle of term. Even with over 25 years of online and distance experience, this is new territory... Moving over from in-person to remote during the course itself is a bit like trying to change the tire on a car while it is still driving down the highway" (Kennepohl, 2020, p. i).

On the other hand, EOT emphasized the value of collaboration as Teacher 2 preferred remote classes considering her observations on how parents guide their kids in doing their homework and assist the kids during classes.

Teacher 2: The benefit from online classes is that it strengthens the relationship with the teachers and students as well as with the parents. It seems that parents are mostly guided how to help their kids in doing their homework and parents may know how their kids behave during classes. Personally, I prefer online classes because I have seen how parents guide their kids in doing their homework and that they always stay at the side of the kids during classes to assist them in answering questions I ask.
The concepts presented here can open up the benefits of emergency online teaching such as convenience and collaboration. These are apparent in the responses of the Philippine teachers. In addition, emergency online teaching is accessible to teachers and students as they do not need to travel in order to attend classes. Likewise, intellectual and social partnership in emergency online teaching are developed among teachers and students as they are able to engage in the virtual classroom (Posey, Burgess, Eason, \& Jones, 2010).

Challenges. For the challenges of emergency online teaching as perceived by the Filipino teachers, five themes emerged which include: technical problems, class size, learning materials, student engagement, and learning environment. Among the six Filipino teachers, four teachers identified the technical problems as one of the challenges in emergency remote teaching. According to Teacher 1, "I think aside from the internet connection, the communication is more challenging and appropriate gadgets or technology." Likewise, Teacher 4 and Teacher 5 mentioned "slow or unstable internet connection."

Teacher 6: Teaching online is challenging especially with technical problems involving disrupted internet connection.

These concepts were supported by Posey, Burgess, Eason, and Jones (2010) as they explained that the disadvantage of technology and reliance on internet includes viruses and slow internet connection. That is why it is pertinent for the government to issue legal regulations to prioritize the connection of high quality broadband for educational use (Zhang, Wang, Yang, \& Wang, 2020).

Aside from technical problems, the class size is also considered as one of the challenges. The problem with the class size were mentioned by Teacher 1 "large group of classes," and emphasized by Teacher 2 :

During the first day , I tried to have all kids in a class but I felt so bad that I couldn't accommodate all of them, the time is too short for all the 13 students, I couldn't ask each and not all kids could share their ideas. So I divided the kids into two classes and I extended half an hour. Online class is not suitable for big group of kids.

The issue on the large group of classes is not new in online teaching. However, with regard to the primary learners as well as their level and low attention span, their case is very different from the students in higher education. It is important to consider the class size in teaching online for the teacher to manage the class and secure that every learner can participate and interact. Hence, according to Reonieri (2006) small class size in online teaching includes 5-10 learners. In addition, having small class size is optimal for teachers as they can give more time to facilitate the activities and learners' engagement in online class.

On the other hand, issues on the learning materials were mentioned by the Teacher 3 "head bursting Power Point presentation (PPT), as I have to make an interesting (PPT) for 3-6 years old kids with no background in English." Considering the short span of attention among kids, teachers are expected to make interactive presentations to get the attention of the students. Hence, this burden lies on the shoulders of Filipino teachers as they embark to the new trend in education. This is reinforced by Kebritchi, Lipschuetz, and Santiague (2016) as they implied that remote teachers may not know what to prepare concerning the transition in education. One of the challenges in emergency remote teaching is the preparation of their needed learning materials as they 
have to generate new strategies to get the attention of the learners to participate actively in the virtual class.

Teacher 1: For me it's challenging to make a creative and interactive PPT since the school doesn't have the pre designed system of curriculum.

To reinforce the idea suggested by the response of Teacher 1 , problems with the curriculum and content development arise due to the sudden transition of face-to-face teaching method to online teaching (Kebritchi, Lipschuetz, \& Santiague, 2016). Evidently, online teaching requires an adequate planning (Palvia et al., 2018) and a comprehensive and well-built curriculum which is contrary in this scenario. The unreadiness in this scenario that the teachers' experience is due to a sudden shift to virtual education, so they make use of materials that are available and there is no 'pre-designed curriculum'in Emergency Remote Teaching because it happens as a response to an unprecedented emergency.

With regard to student engagement, Teacher 4 mentioned that "some students can't really pay attention to the lesson, especially the little ones." This was further reinforced by Teacher 6 who said that "students have less focus during class." Likewise, according to Quevillon (2018), passive students is one of the challenges in online teaching. Similarly, according to Kebritchi, Lipschuetz, and Santiague (2016), learners' attitude in online class is a major issue as discussed by the researchers considering the learners' passive participation than the expected active engagements.

Teacher 5: I think the students' engagement is the most challenging part. Most of my new students are very young, shy, or have no interest in learning the language. A 30 minute session is a struggle especially when the internet connection is unstable.

Such idea is supported by Sorensen (2014) as he implied that making students participate and making connections with them (Ducan \& Young, 2009) in an online class is a challenge to teachers as they should encourage the students to think and elaborate their thoughts.

Furthermore, the issues with the learning environment were identified by two teachers. Teacher 4 said that "online teaching is challenging with noisy environment." She also added that this kind of teaching causes "eyestrain for both teachers and students."

Teacher 6: Getting the attention of my learners is challenging because of some factors in their location like a noisy sibling and a room not conducive for learning.

This environment issue happens in an emergency situation since there is a lack of necessary and lengthy preparation time for a wellestablished online curriculum that includes the consideration for a conducive learning environment, so through the concept of an emergency remote teaching, the teachers need to find ways to deal with the situation at hand to continue the access for instruction to the students despite the crisis.

Process. To have a gist of how the teachers implement emergency remote teaching, four themes were obtained from the responses of the Filipino teachers which include instructional design, assistant teacher, class rules as well as rewards and punishments.
Regarding instructional design, Teacher 1 mentioned "I usually write lesson plan (design), make PPT for better interaction and to keep the attention of the students, present, practice and outright checking of output." In view of this, planning of the lesson was done by the teacher, followed by present, practice, and evaluation through checking of output. Meanwhile, Teacher 6 said "I usually present PPT and let the kids describe what they see, they respond well if the pictures are colorful."

Teacher 5: I always use interactive PPT in all my classes. All the teaching steps (warm up, presentation, practice, production, wrap up) are included in the presentation. The class rules are made simpler with corresponding pictures for better understanding. Roll call and scoring are also designed according to the interest of the students. Aside from using interesting graphics, I also use TPR and props to help students understand the content better.

The strategy of Teacher 5 posits student engagement activities considering the use of interactive PPT, pictures, graphics, and Total Physical Response (TPR) which is suitable for young learners due to the harmony of speech and action (Er, 2013). As such, active participation of learners is observed as they are able to engage with the activities prepared in the class. This is reinforced by Har, Abidin, and Saibon (2019) as they suggest that the teaching effectiveness in using technology depends on the learners' level of engagement on the prepared technological based activities. Furthermore, the use of instructional design helps the teachers as well as the learners to take control of learning. It also promotes engaging, evocative, and vigorous learning among learners (Chen, 2016).

To implement a successful instructional design or strategies, Filipino teachers seek the assistance of the Chinese teachers to deal with the kids as well as the parents to make sure that learners understand the instructions of the Filipino teachers considering a different language context. Among the six Filipino teachers, 50\% prefer to have a teacher assistant. Teacher 3 mentioned "I do online teaching with the help of Chinese teacher and body language." With regard to the response of Teacher 3, the use of "body language" is quite interesting. Yet, such strategy in online teaching is difficult to do in online teaching for some teachers (Bao, 2020).

In addition, Teacher 4 said, "learners are given clear instructions from the start and the Chinese teacher help translate on what they are expected to do/behave in class."

Teacher 2: In my experience, with the help of assistant teacher, the class is going smoothly, I am giving the lessons while the assistant teacher is the one putting the kids in the screen and turning on/off their microphone. So I would say that we got a good team for our online class.

To reinforce the idea implied by Teacher 4 in the process of implementation of emergency remote teaching, obtaining backing from the teacher assistants can serve as a helpful support (Bao, 2020) in managing the atmosphere for a conducive flow of learning among the students in a virtual class. The idea for the teaching assistants is to allow the lead teacher to focus on the core of instruction. Teacher 4 added that teacher assistants could also assist teachers with the technological aspects of online teaching. 
Furthermore, to create an organize and disciplined remote class, some Filipino teachers are very strict with rules for the kids to follow. According to Teacher 2, "during the first day of class, I presented the rules during our class for kids to get oriented and follow. At first I showed pictures of the rules later on I just ask kids every time we start our class and they have remembered. Consistency is the key for kids to follow the instructions."

On the other hand, Teacher 4 employs reward and punishment to discipline the kids in her class. She mentioned, "I implement reward and punishment by giving stars to kids if they do well or taking them away if they misbehave. The parents are also informed about their child's performance and behaviour in the class."

With regard to the implementation of the rewards and punishment by Teacher 4 , it is one way for learners to learn desired actions or rules in the class. This concept is supported by Ho, Littman, Cushman, and Austerweil (2015) as they implied that the use of rewards and punishments creates positive learning cycles concerning learners' actions in the class. Using the reward and punishment strategy is one of the significant processes that the teachers employ for an effective implementation on instruction through emergency remote teaching.

\section{IMPLICATIONS}

The benefits and challenges of emergency online teaching are apparent in the responses of the Philippine teachers. Considering the benefits of emergency online teaching, this study implies that teachers should not only rely on the convenience of emergency online teaching due to the unpredictable internet connection and technical problems that may occur (Posey, Burgess, Eason, \& Jones, 2010). The potential collaboration or formation of connections in the education sector can develop the social capital of the Philippine teachers and Chinese counterparts for emergency online teaching which opens a positive stance in education. With regard to the challenges in emergency online teaching, the teachers who are teaching online or remote classes should also seek the assistance of technicians aside from Chinese teacher assistants to secure good internet connection and availability of gadgets. In addition, the learning environment, class size, learning materials, and students' engagement in online class (Kebritchi, Lipschuetz, \& Santiague, 2016) should be taken into consideration in the implementation of an emergency online education. The study suggests that schools which are offering distance education classes should make use of emergency online education during this crisis and collaborate with teachers to organize the necessary preparations as a temporary solution for a conceivable virtual-based education during this pandemic. With regard to the implementation of emergency online teaching, curriculum developers along with the cooperation of teachers should develop instructional designs or models based on the context of the pandemic, so that the teachers can be guided on the process of emergency online education, and learners will be able to engage in the virtual class activities (Chen, 2016). Furthermore, the use of rewards and punishments in emergency online teaching posits a constructive way of employing discipline among learners as they will be aware of the consequences of their actions (Ho, Littman, Cushman, \& Austerweil, 2015).

\section{LIMITATIONS}

The results herein do not speak for the entire teachers who are teaching remote classes considering the small sample of the Philippine teachers who participated in this study. Likewise, this study captured only five dimensions from the model of Khan: pedagogical, institutional, technological, management, and resource support; while interface design, ethics, and evaluation dimensions of the implementation of emergency online teaching of the teachers were not explored in the study. Nevertheless, the findings show considerable data to guide curriculum developers, school administrators, and novice distance education teachers in the implementation of emergency online teaching or emergency remote teaching during this pandemic and in another possible crisis that can arise in the future. Further studies should create an emergency remote teaching/ emergency online teaching model so that schools can continue to mitigate the vulnerabilities in the educational setting in an emergency situation.

\section{CONCLUSION}

Online teaching is not a new notion in education, however, emergency online teaching is the appropriate concept during this crisis since the pandemic presents a lack of time for comprehensive preparation to migrate the courses to an online education curriculum. COVID-19 also presents a heavy toll to those teachers who are not accustomed to using the online platform in teaching the students. Thus, emergency online education or emergency remote education allows schools, teachers, and students for temporary access to online or remote instruction that is easy to set up, practical, and realiable during an emergency. Based on the results, teachers and learners benefit from emergency online/remote teaching because it is convenient and creates collaboration among teachers and learners. However, emergency online/remote teaching is challenging for teachers as they experience technical problems and insufficient educational resources. Another issue is the language barrier since the teachers and the learners are from distinct language background. This study also highlights that a teacher assistant is necessary in the implementation of emergency online teaching. Hence, an instructional design or model is vital in emergency online/remote education to guide the teachers for their virtual classes during this crisis. Likewise, it is important to establish engaging activities for the learners to elicit their ideas to make a virtual class interactive and generate a successful teaching and learning process even amidst the pandemic. Implementing rewards and consequences as a pedagogical strategy can also help teachers to manage an emergency online class. Nevertheless, teachers need to explore more pedagogical online strategies that are viable for emergency online education during this educational crisis.

\section{REFERENCES}

Abdulamir, A. S., \& Hafidh, R. R. (2020). The Possible Immunological Pathways for the Variable Immunopathogenesis of COVID-19 Infections among Healthy Adults, Elderly and Children. Electronic Journal of General Medicine, 17(4), em202. https://doi.org/10.29333/ ejgm/7850 
Affouneh, S., Salha, S., \& Khlaif, Z. (2020). Designing Quality ELearning Environments for Emergency Remote Teaching in Coronavirus Crisis. Interdisciplinary Journal Virtual Learning in Medical Sciences, 11(2), 135-137. https://doi.org/10.30476/IJVLMS. 2020.86120 .1033

Bao, W. (2020). COVID-19 and online teaching in higher education: A case study of Peking University. Human Behavior and Emerging Techologies, 2(2), 113-115. https://doi.org/10.1002/hbe2.191

Bozkurt, A., \& Sharma, R. (2020). Emergency remote teaching in a time of global crisis due to CoronaVirus pandemic. Asian Journal of Distance Education, 15(1), i-vi.

Chen, L.-L. (2016). A Model for Effective Online Instructional Design. Literacy Information and Computer Education Journal, 6(2), 2303-2308. https://doi.org/10.20533/licej.2040.2589.2016.0304

Duncan, H. E., \& Young, S. (2009). Online pedagogy and practice: Challenges and strategies. The Researcher, 22(1), 17-32. Retrieved from https://www.researchgate.net/publication/282662578

Er, S. (2013, October). Using Total Physical Response Method in Early Childhood Foreign Language Teaching Environments. Procedia Social and Behavioral Sciences, 93, 1766-1768. https://doi.org/10.1016/j.sbspro.2013.10.113

Gewin, V. (2020, March 24). Five tips for moving teaching online as COVID-19 takes hold. Career Feature, Nature. Retrieved from www.nature.com: https://www.nature.com/articles/d41586-02000896-7

Gondauri, D., Mikautadze, E., \& Batiashvili, M. (2020). Research on COVID-19 Virus Spreading Statistics based on the Examples of the Cases from Different Countries. Electronic Journal of General Medicine, 17(4), em209. https://doi.org/10.29333/ejgm/7869

Har, A. L., Abidin, M. J., \& Saibon, J. S. (2019). The benefits and drawbacks of using tablet-based digital storytelling in vocabulary learning among Malaysian young English as a Second Language (ESL) learners. Asia Pacific Journal of Educators and Education, 34, 1747. https://doi.org/10.21315/apjee2019.34.2

Ho, M. K., Littman, M. L., Cushman, F., \& Austerweil, J. L. (2015). Teaching with Rewards and Punishments: Reinforcement or Communication?, 920-925. Retrieved from cushmanlab.fas.harvard.edu:

https://cushmanlab.fas.harvard.edu/docs/Ho_etal_2015.pdf

Hodges, C., Moore, S., Lockee, B., Trust, T. \& Bond, A. (2020, March 27). The Difference Between Emergency Remote Teaching and Online Learning (Blog post). Retrieved from https://er.educause.edu/articles/2020/3/the-difference-betweenemergency-remote-teaching-and-online-learning

Kebritchi, M., Lipschuetz, A., \& Santiague, L. (2016). Issues and Challenges for Teaching Successful Online Courses in Higher Education: A Literature Review. Journal of Educational Technology Systems, 46(1), 4-29. https://doi.org/10.1177/0047239516661713

Kennepohl, D. (2020). Editorial. International Review of Research in Open and Distributed Learning, 21(2), i-iii. https://doi.org/10.19173/ irrodl.v21i2.4812
Khan, B. H. (Ed.). (2005). Managing e-learning: Design, delivery, implementation, and evaluation. IGI Global. https://doi.org/10.4018/978-1-59140-634-1

Lin, L. (2002). English Education in Present-day China. Retrieved from www.accu.or.jp: http://www.accu.or.jp/appreb/09/pdf33-2/332P008-009.pdf

Murphy, M. P. A. (2020). COVID-19 and emergency eLearning: Consequences of the securitization of higher education for postpandemic pedagogy. Contemporary Security Policy, 41(3), 492-505. https://doi.org/10.1080/13523260.2020.1761749

Palvia, S., Aeron, P., Gupta, P., Mahapatra, D., Parida, R., Rosner, R., \& Sindhi, S. (2018). Online Education: Worldwide Status, Challenges, Trends, and Implications. Journal of Global Information Technology Management, 21(4), 233-241. https://doi.org/10.1080/ 1097198X.2018.1542262

Posey, G., Burgess, T., Eason, M., \& Jones, Y. (2010). The Advantages and Disadvantages of the Virtual Classroom and the Role of the Teacher. Retrieved from www.swdsi.org: http://www.swdsi.org/ swdsi2010/SW2010_Preceedings/papers/PA126.pdf

Quevillon, K. (2018, January 31). Online Teaching: 4 Unique Challenges and How to Solve Them. Retrieved from tophat.com: https://tophat.com/blog/online-teaching-challenges/

Reonieri, D. C. (2006, December 05). Optimizing the Number of Students for an Effective Online Discussion Board Learning Experience. Retrieved from eric.ed.gov: https://eric.ed.gov/ ?id=ED494890

Sorensen, C. (2014, December). Classrooms Without Walls: A Comparison of Instructor Performance in online Courses Differing in Class Size. MERLOT Journal of Online Learning and Teaching, 10(4), 569-576.

Talidong, K.J. (2020). Implementation of emergency remote teaching (ERT) among Philippine teachers in Xi'an, China. Asian Journal of Distance Education, 15(1), 196-201. Retrieved from http://asianjde.org/ojs/index.php/AsianJDE/articleview/463

Toquero, C. M. (2020a). Challenges and Opportunities for Higher Education amid the COVID-19 Pandemic: The Philippine Context. Pedagogical Research, 5(4), em0063. https://doi.org/10.29333/pr/ 7947

Toquero, C. M. D. (2020b). Emergency remote teaching amid COVID19: The turning point. Asian Journal of Distance Education, 15(1), 185188. Retrieved from http://asianjde.org/ojs/index.php/AsianJDE/ articleview/450

UNESCO (2020). Global Monitoring of School Closures caused by COVID-19. Retrieved from https://en.unesco.org/covid19/ educationresponse

Zhang, W., Wang, Y., Yang, L., \& Wang, C. (2020). Suspending Classes Without Stopping Learning: China's Education Emergency Management Policy in the COVID-19 Outbreak. Journal of Risk Financial Management. 13(3), 55. https://doi.org/10.3390/ jrfm 13030055 